\title{
THE CONSUMER PROTECTION AS A DRIVER OF INNOVATIVE DEVELOPMENT: CASE STUDY FOR CONSUMERS OF FINANCIAL SERVICES
}

Today, there is a clear understanding of the concept of "financial accessibility" as a necessary condition for sustainable poverty reduction, innovation and economic growth. However, the relationship between financial availability and traditional for the financial sector to ensure the stability, integrity and protection of consumers of financial services has not been sufficiently studied and not considered in a single context. This situation began to be corrected and acquired a special urgency in the post-crisis period, when the study of this problem could help to understand the causes of the onset of financial structural changes. The purpose of the paper is a research of the nature of implicit connections between the level of protection of consumers interests of the financial services market as drivers of innovation development in the country, and three conditional sectors: general economic status, public administration and financial stability. The basis of the study was the statistical information of the IMF, CGAP and the World Bank on the Financial Access 2010 database, the Global Findex database and the G20 Financial Inclusion Indicators of the World Bank, the database of OECD/INFE on Adult Financial Literacy at the time of 2010 for 95 countries with different levels of economic development. The system of simultaneous structural equations was used as a method for calculations. 31 indicators were selected for formalizing the implicit structural links between the four contingent sectors: the general economic condition of the countries, public administration, financial stability of the countries and the level of protection of the interests of consumers of the financial services market, among which 12 major components were selected by the method of main analysis, included for further analysis. The formalization of the relationships between the latent variables introduced in the study allowed the following conclusion: with an increase in the level of protection of the interests of consumers of the financial services market, the level of public administration and the general economic state is growing. Thus, it was confirmed the thesis that the level of consumer protection in case of consumer financial services market fulfills the role of a locomotive for innovative development of the country as a whole.

Keywords: innovation development, financial attraction of population, financial accessibility, financial stability, economic growth, state regulation, World Bank.

Introduction. The success of the innovative development of the financial sector depends directly on the number of satisfied customers involved on it. Very often the reason for financial instability in the country is precisely the unwillingness of the population to perceive all that flow of financial information, which pervades and continually changes, acquiring new forms.

The constant updating of world financial trends may simply not be accepted by residents of a particular region, given the financial traditions that accompany all their activities. Financial policy, as a set of measures aimed at redistributing available resources in the financial system, must necessarily also ensure financial availability, financial literacy, financial integrity and stability, which will undoubtedly become the basis for protecting the rights of consumers of the services of the financial sector. All of the abovementioned high-quality financial policy tasks require special attention from the regulator, as they do not have a clear quantitative expression that could be compared with the reference values and draw conclusions about compliance / non-compliance with the set standards. However, in many scientific papers it has been proved that financial accessibility or, in other words, the level of financial attraction of 
the population has a direct positive relationship with financial stability, while this relationship is not unilateral.

However, the relationship between financial availability and traditional for the financial sector to ensure the stability, integrity and protection of consumers of financial services has not yet been sufficiently studied and not considered in a single context. This situation has begun to be corrected and has become especially relevant in the post-crisis period, when the study of this problem could help to understand the causes of the onset of financial structural changes.

Analysis of recent research and publications. A group of researchers led by Demirguk-Kunt in his research analyzes the impact of financial accessibility (attraction of the population) on economic growth at the household level. Yes, they form the following set of key features of financial accessibility, which are the key to an innovative breakthrough of the state:

- financial availability at the basic level begins with a deposit or a current account with a bank or other financial institution;

- Financial accessibility includes access to credit services by official financial institutions that allow people to invest in education or to open and expand their own businesses;

- Due to financial availability, access to insurance products helps people to better manage financial risks

- Financial accessibility benefits society through the implementation of financial transactions from an account to an account instead of cash payments, which undoubtedly increases the efficiency and transparency of cash flows.

The last feature of financial availability can help the population to get their own payment history, which underlies the formation of a customer's credit history. Thus, in the US, due to the inclusion of information on payment of utility and other regular payments to the customer's credit history, the number of consumers of the financial market with a high credit rating has increased. It was found that the greatest similar positive effect was observed among low-income citizens, national minorities, youth and the elderly. The essence of the study in India was to test the effect of micro-credit on women in 15 to 18 months and 3 years after it was issued. In this case, the received microcredit did not trigger the emergence of a new business, however, increased investment in the existing business and the profitability of these small and medium enterprises increased on average. It should be noted that the increase was due to a small number of the most successful enterprises. Households under the influence of microcredit began to invest more in longer-term products and spend less on goods of secondary needs.

The result of the insurance sector's activities insurance products can also be a very important tool for managing financial risks. The researchers note that at the minimum level of insurance people with low incomes prefer receiving low income at low risk for it. In one of the papers devoted precisely to the problem of determining the degree of connection between financial attraction and financial stability, it is proposed to divide the indicators on the basis of which the financial attraction of the population can be estimated into four blocks (Table 1).

Table 1 - The system of developed sets of indicators for assessing the level of financial attraction of the population

\begin{tabular}{|l|l|}
\hline Title of unit & Indexes \\
\hline Access & - physical availability of banking and other financial services for the population \\
\hline Quality & - number of accounts opened in various financial institutions \\
\hline Using & - share of the population having accounts in any financial institution \\
\hline Influence & - an assortment of financial products and services presented on the market \\
\hline
\end{tabular}

In order to achieve the highest possible values of these indicators, it is necessary to take into account the key principles of the Center for Global Development: 
- free entry into the market and competition between financial institutions;

- creation of a sufficient number of legal and informational institutions of a financial nature that would provide a powerful infrastructure;

- stimulation of information demand for financial products and services;

- ensuring an adequate level of security and reliability of financial service providers;

- protection of consumers' rights with a middle and low standard of living from aggressive policy of financial institutions;

- ensuring the effective implementation of existing regulations;

- strengthening coordination between interregional financial institutions;

- Balancing the role of the government with market supply of financial products and services;

- effective use of subsidies and taxes;

- ensuring the systematic collection, monitoring and evaluation of the financial market.

In the context of the problem of determining the strength and direction of the link between the level of financial attraction of the population and the financial stability of the country, it is worth paying attention to the study, which analyzes the relationship between the level of maximum fall in the growth rate of deposits and deposits of commercial banks and the level of financial attraction of the population, as the proportion of the adult population that keeps its funds in financial institutions. In this paper, a special emphasis was placed on the fact that the presence of this kind of interconnection is the basis for the formation of the country's innovative potential. The role of the dependent variable fulfilled the maximum volume fall in the growth rate of deposits and deposits, which was expressed as the difference between the maximum and the minimum annual growth rate. In addition to the level of financial attraction of the population, the total population, GDP per capita, the level of inflation, the fictitious change in the crisis / non-crisis general condition of the country's economy, the GDP growth rate, the fictitious change in the availability / absence of an effective system of deposit insurance in the country, were used as independent (factor) variables, Zsore of the banking sector, the ratio of banks' liquid assets to aggregate deposits, the ratio of loans issued to the volume of attracted bank deposits, an indicator of capital's openness $x$ accounts. In total, the study involved 95 countries with different levels of economic development. As a result, it was found that in the middle-income countries a higher proportion of the adult population that retains its funds in financial institutions has a stronger influence on the stability of the growth rate of deposits and deposits of commercial banks than in high- and low-income countries. In general, an increase in the share of adult population that retains its funds in financial institutions by $10 \%$ leads to a decrease in the difference between the maximum and minimum annual growth rates from 3 to $8 \%$.

Another, equally interesting study on similar topics was held in 100 different countries on the basis of dynamic panel data model. As indicators that identified the financial stability of the country acting as a dependent variable, the Z-score of the banking sector and the share of overdue credit debt in the total loan portfolio were used. The set of indicators of financial attraction of the population at the same time consisted of the share of active loans issued to small and medium-sized businesses, in the total portfolio of active loans of commercial banks, the share of small and medium-sized businesses in the total number of active borrowers of commercial banks. The controlling variables were GDP per capita, GDP share of loans issued by commercial banks and other financial institutions, the ratio of liquid assets to total bank deposits, the share of indirect foreign investment in GDP, the indicator of financial openness of the country. The results of the study showed that a higher proportion of active loans issued to small and medium-sized businesses in the aggregate portfolio of active credit of commercial banks results in a higher value of the Z-score of the banking sector, which means a lower probability of a default situation for commercial banks. At the same time, the increase in this indicator negatively affects the share of overdue debt in the total portfolio of loans issued by commercial banks. With regard to the share of small and medium-sized businesses in the total number of active borrowers of commercial banks, the increase of this indicator also 
causes the growth of the Z-sore banking sector.

In the next paper, by the authors of Garcia, the relationship between financial stability and financial accessibility is investigated by building a correlation model based on data from 2008 to 2016 in more than 150 countries of the world. As a resource base for the required statistical indicators, the Financial Access Survey of the International Monetary Fund, the World Bank's Global Findings Global Financial Market Access Database and the Global Financial Development Database (World Financial Development Database). The results of the input data array had the following form:

- number of divisions of commercial banks and non-bank financial institutions;

- number of access points to financial services;

- number of ATMs of commercial banks;

- number of deposits per 1,000 people. adult population;

- the number of credit agreements per 1,000 people. adult population;

- the ratio of "non-working" bank loans to the total value of a bank loan portfolio;

- bank capital;

- bank assets;

- other indicators of financial availability.

In addition, indicators were also added to the analysis of financial stability, which included indicators of flexibility, volatility and banking crises.

The purpose of the paper is the research of the nature of the implicit relationships between the level of consumer protection financial services market as a driver of innovation and conventional three sectors: the general economic situation, governance and financial stability.

Presentation of the main material. As input data in the study used statistical data of IMF, CGAP and the World Bank the Financial Access 2010 database, Global Findex database and G20 Financial Inclusion Indicators of the World Bank, database of OECD / INFE about Adult Financial Literacy at the time of 2010 for 95 countries of the world with different levels of economic development. So, in accordance with the stated purpose, it is necessary to investigate the connection not between specific indicators, but between the spheres based on them, as a method for calculations, we use the system of simultaneous structural equations. The first who began to develop structural modeling in the world was Professor and Director of the Institute for Advanced Studies in the Integrative Sciences at the State University of the. J. Mason (George Mason University) in Virginia J. Warfield. In 1973, based on the foundations of discrete mathematics, the scientist developed a methodology for modeling by structural equations, which allows the investigation of various complex systems based on the detection of hidden links between them. The first resonance of J. Warbield's scientific work, where he used the developed methodology, was devoted to the analysis of complex socio-economic systems. The main advantage of structural modeling is that it allows you to identify some hidden factors, the links between which to some extent precisely explain the structure of the phenomenon under study. From the point of view of the mathematical representation of systems of structural equations distinguish systems of independent and interrelated (recursive, common, simultaneous) equations. The main difference between these approaches is the nature of the presentation of variables. Unlike independent systems, where each equation of the system is actually a separate regression equation, in systems of interdependent equations both dependent and independent variables act simultaneously as one another in different equations. Therefore, each subsequent equation of this system cannot be considered without the previous one. It is precisely the systems of simultaneous structural equations that have become most widely used in scientific research, since they allow to detect the presence of those hidden links between the studied variables. The general view of the system of simultaneous structural equations is as follows: 
S. Poliakh. The Consumer Protection as a Driver of Innovative Development: Case Study for Consumers of Financial Services

$$
\left\{\begin{array}{l}
Y_{1}=a_{11} x_{1}+a_{12} x_{2}+\cdots+a_{1 n} x_{n}+\varepsilon_{1}, \\
Y_{2}=b_{21} Y_{1}+a_{21} x_{1}+a_{22} x_{2}+\cdots+a_{2 n} x_{n}+\varepsilon_{2}, \\
Y_{3}=b_{31} Y_{1}+b_{32} Y_{2}+a_{21} x_{1}+a_{22} x_{2}+\cdots+a_{2 n} x_{n}+\varepsilon_{2}, \\
\cdots \cdots \cdots \cdots \cdots \cdots \cdots \cdots \cdots \\
Y_{m}=b_{m 1} Y_{1}+b_{m, m-1} Y_{m-1}+a_{m 1} x_{1}+a_{m 2} x_{2}+\cdots+a_{m n} x_{n}+\varepsilon_{m}
\end{array}\right.
$$

where $Y_{m}$ - dependent variable (endogenous); $x_{n}$ - independent variable (exogenous); $b_{m n}$ i $a_{m n}-$ structural coefficients of the model; $\varepsilon_{m}$ - residual value.

31 indicators were selected for the formalization of implicit structural links between the four contingent

\begin{tabular}{|c|c|}
\hline Group indicator & Indicator \\
\hline \multirow{9}{*}{ Total economic condition } & Current account balance \\
\hline & Employers \\
\hline & Exports of goods and services \\
\hline & Foreign direct investment, net outflows \\
\hline & Foreign direct investment, net outflows \\
\hline & GDP per capita \\
\hline & GINI index \\
\hline & Imports of goods and services \\
\hline & Unemployment \\
\hline \multirow{6}{*}{ State Management } & Control of Corruption \\
\hline & Government Effectiveness \\
\hline & Political Stability and Absence of Violence/Terrorism \\
\hline & Regulatory Quality \\
\hline & Rule of Law \\
\hline & Voice and Accountability \\
\hline \multirow{13}{*}{ Financial Stability } & Regulatory Capital to Risk-Weighted Assets \\
\hline & Regulatory Tier 1 Capital to Risk-Weighted Assets \\
\hline & Non-performing Loans Net of Provisions to Capital \\
\hline & Non-performing Loans to Total Gross Loans \\
\hline & Sectoral Distribution of Total Loans: Residents \\
\hline & Sectoral Distribution of Total Loans: Nonresidents \\
\hline & Return on Assets \\
\hline & Return on Equity \\
\hline & Interest Margin to Gross Income \\
\hline & Non-interest Expenses to Gross Income \\
\hline & Liquid Assets to Total Assets \\
\hline & Liquid Assets to Short Term Liabilities \\
\hline & Liquid Assets to Short Term Liabilities \\
\hline \multirow{3}{*}{$\begin{array}{l}\text { Level of protection of } \\
\text { consumer interests in the } \\
\text { financial services market }\end{array}$} & Inclusion to the financial protection scheme \\
\hline & Level of financial education of the adult population \\
\hline & Level of the quality of consumer protection financial market services \\
\hline
\end{tabular}
sectors: the general economic condition of the countries, public administration, financial stability of the countries and the level of protection of interests of consumers of the financial services market (Table 2).

Table 2 - Set of input indicators

The method of principal components for further study were selected 12 indicators. General economic condition: foreign direct investment, net inflows; GDP per capita; GINI index. State Management: control of corruption; government effectiveness; political stability and absence of violence/terrorism. 
Financial stability: regulatory capital to risk-weighted assets; return on assets; return on equity. The level of protection of consumers' interests in the financial services market inclusion to the financial protection scheme: level of financial education of the adult population; level of quality of consumer protection financial market services.

In order to conduct structural modeling, it is necessary to introduce latent (hidden) and explicit variables into the research. In this case, the latent variables will have four deductible segments, and obviously those 12 indicators that represent them. Let's represent the schematic structure of the dependencies between explicit and latent variables (Fig. 1). This is required in order to clearly understand the complexity of the model, which simplifies the process of entering the necessary parameters when computing in a special software.

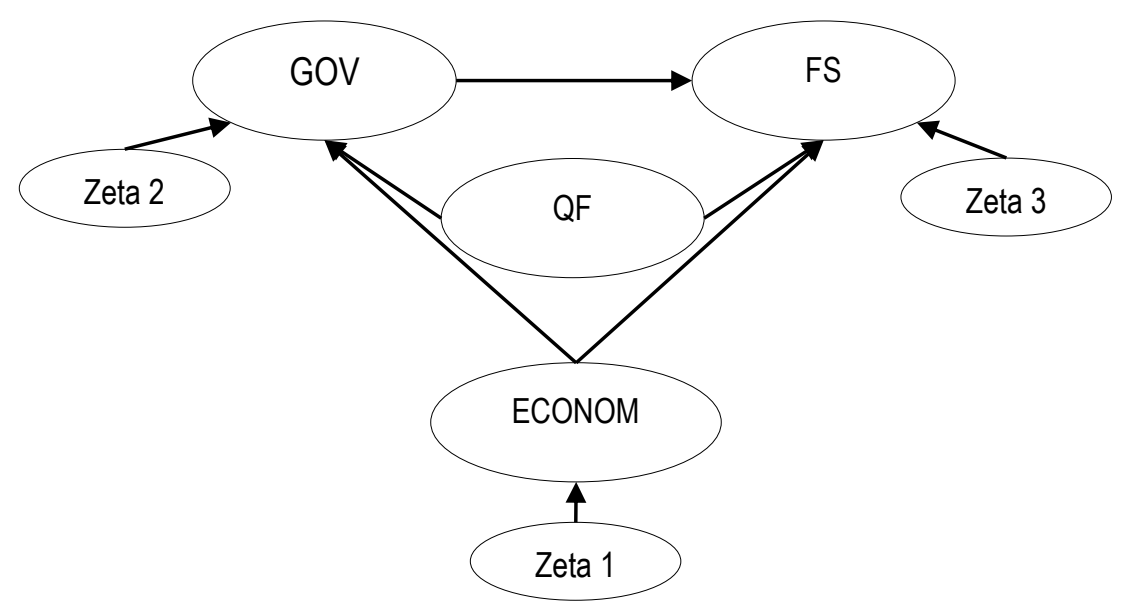

Figure 1 - Structure of inter dependencies between latent variables (GOV - public administration, FS - financial stability, ECONOM - general economic condition, QF - level of protection of interests of consumers of the financial services market, Zeta - residual values with latent variables)

Formalize a schematic representation of interdependencies between latent and manifest variables by using regression equations:

$$
\begin{aligned}
& E C O N O M=a_{1} Q F+\text { Zeta }_{1}, \\
& G O V=a_{2} Q F+b_{1} E C O N O M+Z e t a_{2}, \\
& F S=a_{3} Q F+b_{2} E C O N O M+b_{3} G O V+Z \text { eta }
\end{aligned}
$$

With the help of software implementation in the special module STATISTICA 10, which allows structural modeling, the following linear regression equations were obtained.

$$
\begin{aligned}
& E C O N O M=0,477 Q F+0,512, \\
& G O V=0,534 Q F+0,493 E C O N O M+0,466, \\
& F S=0,450 Q F+0,605 E C O N O M+0,426 G O V+0,448
\end{aligned}
$$

Given the statistical significance of the structural coefficients obtained by the latent variable $Q F$, we can draw the following conclusion: the higher the level of protection of the interests of consumers of the 
S. Poliakh. The Consumer Protection as a Driver of Innovative Development: Case Study for Consumers of Financial Services

financial services market, the higher is the level of public administration and the general economic situation. The quality of the constructed model can be estimated using a number of statistical indicators (Table 3).

Table 3 - Basic statistical indicators that indicate the quality of the constructed model of structural equations

\begin{tabular}{|l|c|c|c|}
\hline \multicolumn{1}{|c|}{ Criterion } & Value Compliance norm & The optimal value & Compliance norm \\
\hline Discrepancy Function & 1,069 & Lower & + \\
\hline Maximum Residual Cosine & 0,000 & Value close to 0 & + \\
\hline Maximum Absolute Gradient & 72,441 & - & - \\
\hline ICSF Criterion & 0,000 & Value close to 0 & + \\
\hline ICS Criterion & 0,001 & Value close to 0 & + \\
\hline Chi-Square Statistics & 100,503 & $>$ Tabular value & + \\
\hline Degrees of Freedom & 51 & - & + \\
\hline Chi-Square p-level & 0,000 & $<0,05$ & + \\
\hline RMS Stand. Residual & 0,109 & $<0,05$ & - \\
\hline
\end{tabular}

We analyzed the presented criteria in the Table 2, we can say that the iterative design process converged successfully ICSF mentioned criteria and ICS close to zero, the functional disagreement lesser value Maximum Residual Cosine close to zero, Chi-Square $p$-level is less than 0.05 . All this testifies to the adequacy of the constructed model. In addition, the adequacy of the model also shows the normal distribution of residues presented in Figure 2.

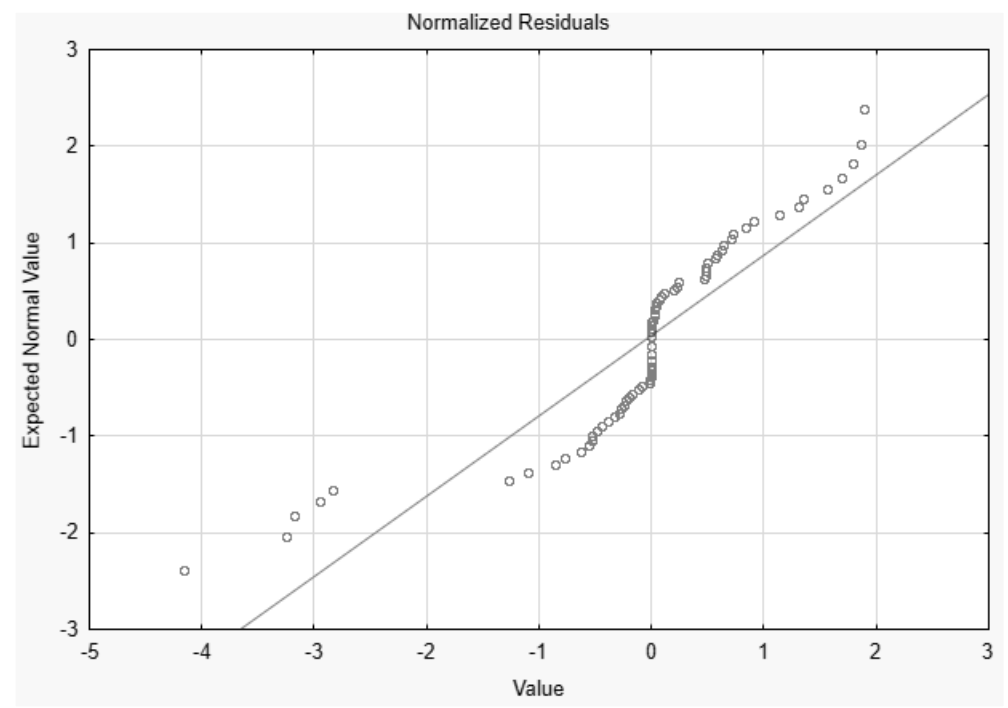

Figure 2 - Normal Probability Plot

So, as the points on this graph are tightly arranged around the line, this indicates the adequacy of the model. Thus, the established interdependence between latent variables was confirmed and the results obtained can be used in further studies.

Conclusion. A study was devoted to the identification of implicit connections between the level of protection of consumers' interests in the financial services market as drivers of the country's innovation 
development and three contingent sectors: general economic status, public administration and financial stability. As a method for calculations, a system of simultaneous structural equations was used. 31 indicators were selected for formalizing the implicit structural relationships between the four contingent sectors: the general economic status of the countries, public administration, financial stability of the countries and the level of protection of the interests of consumers of the financial services market, among which the 12 most important ones were selected by the method of the main components. The formalization of the relationships between the latent variables introduced in the study allowed the following conclusion - the higher the level of protection of the interests of consumers of the financial services market, the higher the level of public administration and the general economic status. Thus, the thesis was confirmed that the level of consumer protection on the example of consumers of the financial services market serves as a kind of locomotive for the innovation development of the state as a whole.

Prospects for further research. The basis of the activities of modern financial institutions are the principles of clarity in the provision of financial information, compliance with the requirements for the introduction of high-quality products and services on the market, continuous support (support) of the consumer, as well as the security of consumer rights. This is the key to the innovative development of not only the financial sector, but also the country as a whole. A significant basis for regulating the activities of financial institutions in certain areas is a number of regulations issued international. One of the most popular in this context are the 10 key principles that should underlie the protection of the rights of clients in the financial sector, developed in 2011 by experts OECD, Financial Stability Board (FSB) and other international organizations at the request of finance ministers of the "Big Twenty" and developed by the World bank and presented in 2012. Good Practices for Financial Consumer Protection. The main disadvantage in developing these provisions is their recommendations and nominalist nature, which in turn complicates the process of assessing the quality of the system to ensure an adequate level of protection of consumers of the financial services market. Therefore, further adjustments should be made based on the results obtained by identifying implicit links between the level of consumer protection and the main vectors of the country's innovation development.

Aaltonen, P.G., E.P. Markowski, and T.A. Kirchner. (2010) Ingredients of financial services customer satisfaction: the case of credit card services. Journal of Academy of Business and Economics. 10(3). 528.

Abreu, Margarida, and Victor Mendes. (2010). Financial Literacy and Portfolio Diversification, Quantitative Finance, 10(5), 515-

Allen, Franklin, Asli Demirguc-Kunt, Leora Klapper, and Maria Soledad Martinez Peria. (2012). The Foundations of Financial Inclusion: Understanding Ownership and Use of Formal Accounts, World Bank Policy Research Working Paper 6290.

Behrman, Jere R., Olivia S. Mitchell, Cindy K. Soo, and David Bravo. (2012). The Effects of Financial Education and Financial Literacy: How Financial Literacy Affects Household Wealth Accumulation, American Economic Review: Papers \&Proceedings, 102(3), 300-304.

Bond R., 2010, Financial literacy and awareness in Ukraine: Facts and Conclusions, [in:] R. Bond, A. Kutsenko, N. Lozitskaya. - K.: USAID FINREP [Electronic resource] / Retrieved from http://www.uaib.com.ua.

CGAP (2009). Financial Access 2009: Measuring Access to Financial Services around the World, Washington, DC: CGAP and the World Bank.

CGAP (2010). Financial Access 2010: The State of Financial Inclusion Through the Crisis, Washington, DC: CGAP and the World Bank Group.

Claessens, Stijn, Patrick Honohan, and Liliana Rojas-Suarez. 2009. "Policy Principles for Expanding Financial Access: Report of the CGD Task Force on Access to Financial Services." Washington: Center for Global Development.

Customer suitability in the retail sale of financial products and services, 2008, The Joint Forum. Bank for International Settlements April, [Electronic resource] / Retrieved from - URL: https://www.iosco.org/lib rary/pubdocs/pdf/IOSCOPD268.pdf.

Demirguc-Kunt, A., Klapper L., Singer D. and others Measuring Financial Inclusion and the Fintech Revolution, The Global Findex Database, p. 133.

Demirguc-Kunt, Asli, Leora Klapper, Dorothe Singer, and Peter Van Oudheusden, (2015). "The Global Findex Database 2014: Measuring Financial Inclusion around the World," World Bank Policy Research Working Paper 7255.

Dias D. (2013) Implementing Consumer Protection in Emerging Markets and Developing Economies A Technical Guide for Bank Supervisors 2013, CGAP/World Bank. 
Eisner, Marc Allen, Jeff Worsham, and Evan J. Ringquist. 2006. Contemporary Regulatory Policy. New York: Lynne Rienner. FSD-Kenya (2009). Definition of a Standard Measure for Consumer Interest Rates in Kenya: A Scoping Study, Nairobi: Kenya. [Електронний ресурc] / Retrieved from http://www.fsdkenya.or

Grady, R. (2012) Consumer Protection in the financial sector: Recent regulatory developments. JASSA, (4): p. 36.

Grady, R., Consumer Protection in the financial sector: Recent regulatory developments. JASSA, 2012(4): p. 36.

Han R., Melecky M. Financial inclusion for financial stability: access to bank deposits and the growth of deposits in the global financial crisis // WB POLICY RESEARCH WORKING PAPER. 2013. No. 6577 (AUGUST).

Hannig A., jansen S. FINANCIAL INCLUSION AND FINANCIAL STABILITY: CURRENT POLICY ISSUES // Adbi working paper. 2010. No. 259 (DECEMBER).

Kang K.H. (2015), "Functions of Financial Consumer Protection Agency and Its Design in Korea", Review of Financial Information Studies, 4(1) Pp. 81-100.

Levitin, Adam J. (2013). The Consumer Financial Protection Bureau: An Introduction", Review of Banking and Financial Law, 32, 321-69. [Electronic resource] / Retrieved from SSRN: http://ssrn.com/abstract=2199678 or http://dx.doi.org/10.2139/ssrn.2199678.

Mak, Vanessa (2012). The Myth of the Empowered Consumer: Lessons from Financial Literacy Studies [Tisco Working Paper Series on Banking, Finance and Services No. 03/2012; Tilburg Law School Research Paper No. 03/2013], [Electronic resource] / Retrieved from: http://ssrn.com/abstract=2077539 or http://dx.doi.org/10.2139/ssrn.2077539.

Messy, F.-A. (2012) The latest development of globally recognized instruments on financial education and consumer protection, in 12th Tokyo Roundtable on Capital Market Reform in Asia: Tokyo, Japan. p. 12.

Morgan P. J., Pontines V. Financial stability and financial inclusion // ADBI WORKING PAPER. 2014. No. 488.

OECD (2012), G20 High-Level Principles on Financial Consumer Protection, Organisation for Economic Co-operation and Development: Paris. p. 7.

OECD (2014a): Effective Approaches to Support the Implementation of the Remaining G20 High-Level Principles of Financial Consumer Protection. Paris: OECD. [Electronic resource] / Retrieved from: www.oecd.org/daf/fin/financial-education/G20-OECDFinancial-Consumer-Protection-.

OECD, G20 High-Level Principles on Financial Consumer Protection, 2011, Organisation for Economic Co-operation and Development: Paris. p. 7.

Peterson, C. L. (2003). Truth, Understanding, and High-Cost Consumer Credit: The Historical Context of the Truth in Lending Act, Florida Law Review, 55: 807-903.

Polat, A., Alsaif A. A. (2014). Consumer Protection in Banking: Investigating the 10 High Level Principles of G20 in Saudi Arabia Journal of Applied Finance \& Banking, vol. 4, no. 3, 2014, 195-215.

Porteous, D. (2009). Consumer Protection in Credit Markets, Policy Focus Note: 1, Financial Access Initiative [Електронний pecypc] / Retrieved from [http://www.financialaccess.org]

Porteous, D. and B. Helms (2005). Protecting Microfinance Borrowers, Focus Note No. 27, CGAP.

Sahay R., Čihák M., N'Diaye P., Barajas A., Mitra S., Kyobe A., Mooi Y. N., Yousefi S. R. Financial Inclusion: Can it meet multiple macroeconomic goals? // IMF Staff Discussion Note. 2015. No. 15 / 17

Shin Y. (2015). Effect of Enforcement of Financial Consumer Protection on Financial Product Investment, International Conference on Social Science.

Shin Y., Kim J. (2015). Effect of Financial Consumer Protection Enforcement on Financial Product Investment in South Korean

Market The SIJ Transactions on Industrial, Financial \& Business Management (IFBM), 3(8).

Sundararajan, V., Udaibir Das, and Plamen Yossifov. (2003), Cross-Country and Cross-Sector Analysis of Transparency of Monetary and Financial Policies, IMF Working Paper 03/94 (Washington: International Monetary Fund).

Sundararajan, V., Udaibir Das, and Plamen Yossifov. (2003). Cross-Country and Cross-Sector Analysis of Transparency of Monetary and Financial Policies, IMF Working Paper 03/94 (Washington: International Monetary Fund).

U.S. G.A.O. (2010). Consumer Finance: Factors Affecting the Financial Literacy of Individuals with Limited English Proficiency,

United States Government Accountability Office, Report to Congressional Committees, GAO-10-518, Washington, DC.

Warfield, John. (1976). Societal Systems: Planning, Policy and Complexity, John Wiley \& Sons, Inc., New York, NY.

Whitford, W.C. (1981). Structuring Consumer Protection Legislation to Maximize Effectiveness. Wis. L. Rev.,; p. 1018

Williams, T. (2013) Who Wants to Watch? A Comment on the New International Paradigm of Financial Consumer Market Regulation. Seattle University Law Review. 36(2): p. 1217.

World Bank - FIRST Consumer Protectionand Financial Literacy Program [Electronic resource] / Retrieved from https://a2ii.org/sites/default/files/reports/world_bank-first_cpfl_program.pdf

World Bank. (2014). Global Survey on Consumer Protection and Financial Literacy: Oversight Frameworks and Practices in 114 Economies. Washington, DC: World Bank. [Electronic resource] / Retrieved from: http://responsiblefinance.worldbank.org/ /media/GIAWB/FL/Documents/Publications/.

WorldBank. (2009). Good Practices for Financial Consumer Protection and Financial Literacy in Europe and Central Asia : A Diagnostic Tool, Washington DC: Private and Financial Sector Development Department Europe and Central Asia Region / The World Bank.

WorldBank. (2011). T., Good Practices for Financial Consumer Protection, Washington DC: International Bank for 
Reconstruction and Development / The World Bank.

Wright I.D.G.D. (2014). International Finance Regulation: The Quest for Financial Stability", Chapter 1, Editor: Ugeux, G, John Wiley \& Sons.

Pokazateli finansovoy ustoychivosti. Rukovodstvo po sostavleniyu. (2007). [Financial stability indicators. Compilation Guide] (in Russian). Washington, DC, USA: International Monetary Fund. Retrieved from: https://www.imf org/external/pubs/ft/fsi/guide/2006/pdf/rus/guide.pdf.

С. Полях, Черкаський навчально-науковий інститут ДВНЗ «Університет Банківської справи» (Черкаси, Україна).

Захист прав споживачів як драйвер інноваційного розвитку: дослідження прикладу для споживачів фінансових послуг

Наразі у світовій практиці сформовано чітке розуміння того, що "фінансова доступність" $є$ необхідною умовою зниження бідності, інноваційного та економічного зростання. Однак зв'язок між фінансовою доступністю та традииійними для ффінансового сектору інструментами забезпечення стабільності, иілісності та захисту інтересів споживачів фінансових послуг $є$ недостатньо вивченими і не розглядаються в єдиному контексті. Дана ситуація набула особливої актуальності в посткризовий період, коли вивчення цієї проблеми могло б допомогти зрозуміти причини настання негативних фінансово-структурних змін. Метою роботи є дослідження характеру неявних зв'язків між рівнем захисту інтересів споживачів фінансових послуг та трансформаційними (інноваційними) змінами в трьох умовних секторах: економіці, публічному управлінні та у фінансовому секторі. Основою дослідження є статистична інформація MBФ, CGAP та Свimового банку (база даних Financial Access 2010), Findex ma Iндикатори фінансової інтеграції G20 Світового банку, базу даних OECD/INFE з фінансової грамотності дорослих на момент 2010 року для 95 країн з різним рівнем економічного розвитку. В якості методу обчислень використовувалася система структурних рівнянь. Було обрано 31 показник для формалізації неявних структурних зв'язків між чотирма умовними індикаторами: економічний стан країн, публічне управління, фінансова стійкість країни та рівень захисту інтересів споживачів фінансових послуд. Застосовані технології фільтрації дозволили для подальшого аналізу відібрати 12 основних компонентів. Формалізація зв'язків між латентними змінами, внесеними в модель, дозволила зробити наступний висновок: з підвищенням рівня захисту інтересів споживачів фінансових послуг зростає якість та ефеективність публічного управління та загальний рівень розвитку економіки. Таким чином, була підтверджена гіпотеза, що забезпечення якісного захисту споживачів послуг (у даному випадку - фрінансових послуг) $є$ необхідною передумовою для активізації інноваційного розвитку країни в иілому.

Ключові слова: інноваційний розвиток, фінансове залучення населення, фінансова доступність, фінансова стабільність, економічне зростання, державне регулювання, Світовий банк. 